\title{
URBAN CONFIGURATION AND WATER BALANCE WITH AQUACYCLE MODEL IN THE BELÉM CATCHMENT, SOUTHERN BRAZIL
}

\author{
Juliana Wilse Landolfi Teixeira de Carvalho \\ Laboratory of Hydrogeomorphology, Federal University of Parana, Geography Department, Curitiba, PR, Brasil \\ ¿u wlt@hotmail.com \\ Irani dos Santos \\ Laboratory of Hydrogeomorphology, Federal University of Parana, Geography Department, Curitiba, PR, Brasil \\ irani69@gmail.com
}

\begin{abstract}
The influence of anthropogenic activities on drainage basins increases the complexity of hydrological systems in urban watersheds due to the increased amount of impervious surfaces and the interaction between natural and constructed drainage systems. Herein, the aim is to verify how water balance components respond to anthropogenic changes in different configurations of urban space. The study focuses on the Belém catchment, located in Curitiba, Southern Brazil city. Simulations were performed using the Aquacycle model to evaluate the water balance of fourteen Hydrologic Similarity Areas, which were delimited based on the integrated analysis of zoning law, and demographic density data. The results show a direct and linear interaction between an increase in impervious areas with an increase in surface runoff and decreases in infiltration and evapotranspiration, demonstrating the relationship among urban configuration and components of hydrological cycle. Linear regression analysis indicates $R^{2}$ of 0.986 between impervious surfaces and surface runoff, 0.956 for evapotranspiration and 0.934 for groundwater recharge. However, streamflow and baseflow parameters showed no sensitivity to the percentage of impervious surfaces, with $R^{2} 0.557$ and 0.244 , respectively. Finally, the results indicate a significant contribution to the water balance resulting from water-supply system leakage and wastewater discharge into the drainage system.
\end{abstract}

Keywords: Urban Hydrology. Impervious surfaces. Hydrologic Similarity Areas.

\section{CONFIGURAÇÃO URBANA E BALANÇO HÍDRICO COM O MODELO AQUACYCLE NA BACIA HIDROGRÁFICA DE BELÉM, SUL DO BRASIL}

\begin{abstract}
RESUMO
A inserção de elementos antrópicos nas bacias de drenagem faz crescer a complexidade dos sistemas hidrológicos em bacias urbanas, em função do aumento de áreas impermeabilizadas e da interação entre os sistemas de drenagem natural e construídos. Este estudo objetiva verificar como os componentes do balanço hídrico respondem às alterações antrópicas em diferentes padrões de configuração espacial urbana. O estudo foi realizado na bacia hidrográfica do rio Belém, situada no município de Curitiba/PR, região sul-brasileira. Foram realizadas simulações no modelo Aquacycle, avaliando-se o balanço hídrico em quatorze Áreas de Similaridade Hidrológica, delimitadas com base da análise integrada da lei de zoneamento e uso do solo de Curitiba e dados de densidade demográfica. Os resultados mostram uma interação direta e linear entre aumento das áreas impermeáveis, aumento do escoamento superficial e diminuição da infiltração e evapotranspiração, demonstrando a relação entre a configuração urbana e os componentes do ciclo hidrológico. A análise de regressão linear indica $\mathrm{R}^{2}$ de 0,986 entre superfícies impermeáveis e escoamento superficial, 0,956 para evapotranspiração e 0,934 para recarga do freático. No entanto, os parâmetros vazão e escoamento de base não mostraram sensibilidade à porcentagem de superfícies impermeáveis, com $R^{2} \quad 0,557$ e 0,244 , respectivamente. Finalmente, tais resultados indicam contribuição significativa no balanço hídrico da bacia, oriunda das perdas na rede de distribuição de água tratada e do lançamento de esgoto diretamente no sistema de drenagem.
\end{abstract}

Palavras-Chave: Hidrologia Urbana. Superfícies impermeáveis. Áreas de similaridade hidrológica. 


\section{INTRODUCTION}

Urbanization is a global phenomenon that is growing significantly in Latin America, Africa and Asia, bringing with it substantial implications that have a wide range of impacts across different spheres and scales (UN-HABITAT, 2016; NAGENDRA, BRONDIZIO and LWASA, 2018). The Brazilian Institute of Geography and Statistics (IBGE, 1980; 2010) indicates that the Brazilian urban population has more than doubled in the last 30 years. This growth, however, is incongruent with infrastructure investment and urban planning, thus placing pressure on natural resources, negatively affecting the life quality, and increasing the risk of disasters, for example, the urban flooding (TUCCI, 2016).

The built urban environment has a strong influence on local water dynamics, primarily due to the growing percentage of impervious surfaces and the associated consequences observed in the water balance (LARSEN et al., 2016). Leopold (1968) demonstrated that urban catchments could experience increases of up to seven times in overland flow. Further researches (see MITCHELL, MEIN and MCMAHON, 2001; LEKKAS, MANOLI and ASSIMACOPOULOS, 2008; LEE et al., 2010; MEJÍA et al., 2014) have shown that the growth of impervious surfaces also increase peak discharge and reduce water residence time, while decreasing evapotranspiration and infiltration.

Mejía et al., (2014) used a stochastic model to analyze and describe the streamflow regime in urbanized basins. They analyzed catchments situated in metropolitan areas around the cities of Baltimore and Washington, D.C., with different percentages of impervious areas. The results reveal a highly dependent relationship between the percentage of impervious surfaces and streamflow, surface runoff and baseflow dynamics.

The insertion of some anthropogenic elements into drainage basins increases the complexity of hydrographic systems in urban watersheds (TUCCI, 2002; MITCHELL, 2005; BOTELHO, 2011), not only due to the increased amount of impervious areas (SCHNEIDER, FRIEDL and POTERE, 2009), but also because of the interaction between natural drainage systems and the water-supply, stormwater drainage and wastewater networks (MITCHELL, MEIN and MCMAHON, 2001). The interactions among these elements lead to different possibilities of water entry, permanence and exit in the urban water cycle, becoming complex to understand and to quantify water balance components and other processes that occur in urban catchments.

Since the beginning of the 21st century, models with a systemic approach have been developed to simulate the urban water balance in order to better understand and quantify such interactions. Efforts have also been directed at understanding the relationships between the configuration of urban space and the watershed's hydrological dynamics. However, most researches and current models focus on drainage processes and solutions for countries in the Global North, which have different water management characteristics and dynamics than those in the Global South (NAGENDRA, BRONDIZIO and LWASA, 2018), such as Brazil.

The norm NBR 9649 (ABNT 1986) mandates that wastewater and stormwater must be discarded separately in Brazil. However, it is common that much of the sewage is discarded directly into the stormwater drainage system, which constitutes a substantial volume to be considered in the water balance. The same occurs with rainwater inflow into wastewater networks.

The Brazilian urbanization model, in association with issues inherent in water resource management, assumes that the responses of some components of the water balance may not be sensitive to increases in impervious surfaces. In this context, and based on the abovementioned issues, this paper aims to verify how water balance components respond to anthropogenic changes in different configurations of urban space, with the Aquacycle model application in Belém catchment, located in the city of Curitiba, Paraná, Brazil.

\section{MATERIAL AND METHODS}

\section{Study Area Description}

The Belém catchment is in the most densely urbanized area of Curitiba, the capital city of the State of Paraná, Southern Brazil. In this paper, the watershed is delimited until the Prado Velho Fluviometric Station (65011400), whose streamflow data were used to calibrate the Aquacycle model, encompassing a drainage area of $42,6 \mathrm{~km}^{2}$ and 35 neighborhoods (Figure 1). 
Figure 1 - Study area location.

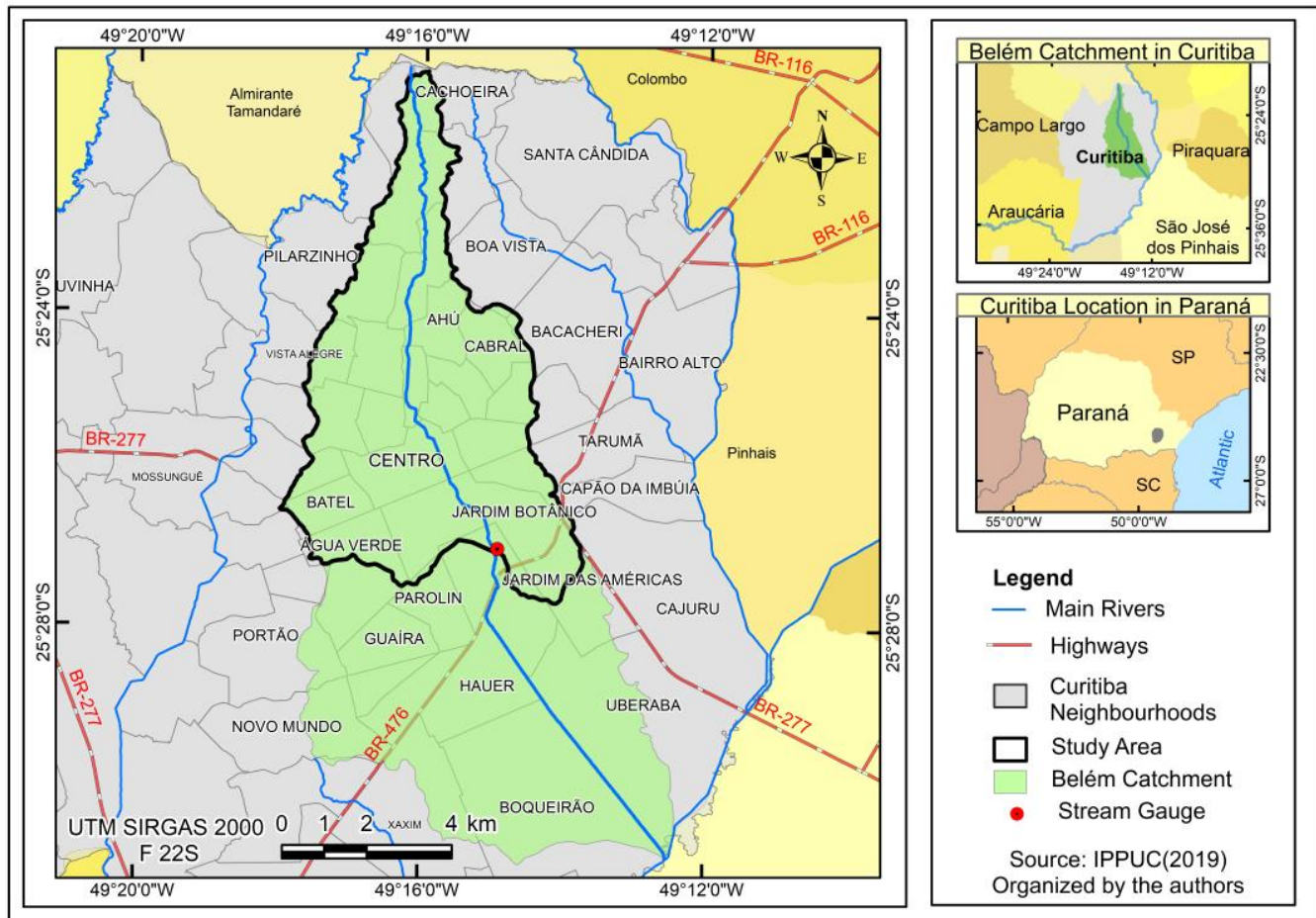

The geology in the study area is covered by Holocene-Pleistocene fluvial and lacustrine sediments (MINEROPAR, 2006). The area is made up of vast alluvial plains with low declivity ( $880 \mathrm{~m}$ to $980 \mathrm{~m}$ ). The soils are characterized by low levels of natural permeability on the slopes and by near-surface water table on the floodplain.

There is a history of flooding and water contamination by domestic and industrial sewage and by diffuse pollution since the end of the 19th century, when the city began to consolidate (CURITIBA MEMORY HOUSE, 1978a). Even after several revitalization, sanitation, and drainage projects (CURITIBA MEMORY HOUSE, 1978b), issues such as urban flooding (FENDRICH, 2002) and water pollution (BOLLMANN and EDWIGES, 2008) continue to have an impact on water resource management. Floods are frequent in the city center and also in the downstream floodplain neighborhoods, which suffer the impacts caused by increases in land area with impervious surfaces throughout the watershed and by rectification and channeling works carried out upstream (FENDRICH, 2002). Water pollution occurs throughout the study area, with a visible upstream to downstream depreciation in water quality (BOLLMANN and EDWIGES, 2008).

\section{Delimitation of Hydrologic Similarity Areas}

To delimit the Hydrologic Similarity Areas (HSA), the catchment was classified into areas that present similar water dynamics characteristics. For this, an integrated analysis that included the Curitiba Zoning and Land Use Law (CURITIBA, 2015) and demographic data (IBGE, 2010) was conducted.

The Zoning and Land Use Law defines important construction standards related to elements that influence the hydrographic dynamics, including the imported water demand, wastewater production, and infiltration, surface runoff and evapotranspiration dynamics, among others. Of these criteria, occupancy rate per building, number of floors and minimum permeable area are particularly relevant. Population density, in turn, directly influences the volume of imported water and wastewater produced.

Based on these criteria, fourteen HSA were delimited (Figure 2). 
Figure 2 - Delimited Hydrologic Similarity Areas.

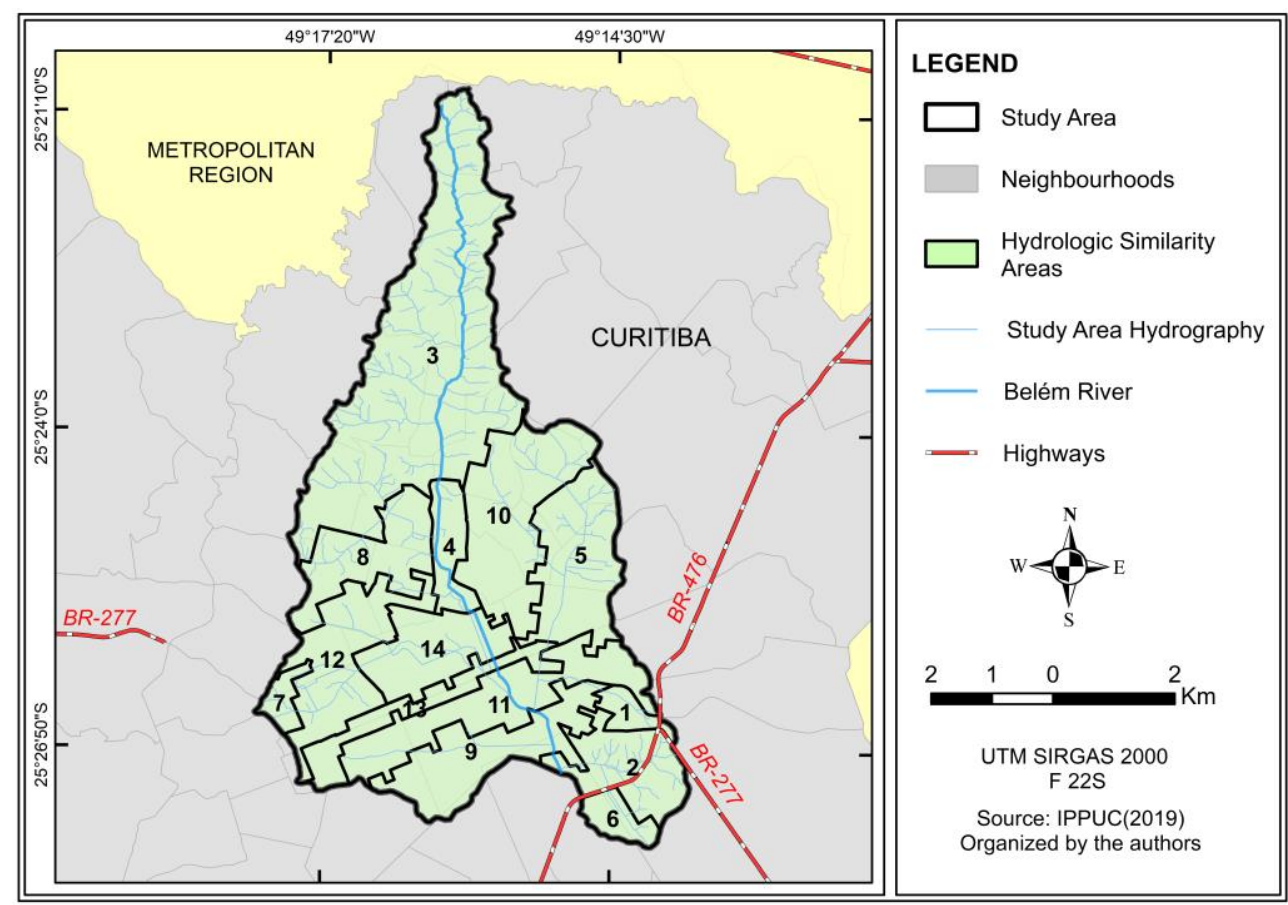

\section{Aquacycle Modelling}

A range of integrated and systemic models have been developed and improved that aim to quantify water balance in urban spaces, such as Aquacycle (MITCHELL, 2005), UVQ (MITCHELL and DIAPER, 2005), SWITCH (LAST and MACKAY, 2007), UWU (DESTRO, 2016), PURRS (SHARMA et al., 2008) and MULTI-HYDRO (VERSINI et al., 2018). Aquacycle has proven effective for urban catchments under different conditions, but to date, no published study has applied the model in Brazil.

Aquacycle is a daily time-step urban water balance model developed to simulate the urban water cycle as an integrated whole. Based on a holistic view of the urban water system, it integrates natural drainage systems and constructed water-supply, wastewater, and stormwater systems in the same modelling structure. It also contains tools to simulate sustainable drainage alternatives (MITCHELL, 2005).

The model uses three spatial scales: unit block, cluster, and catchment. The unit block represents the smallest possible unit for water management: herein defined as the city lot. On the model, the unit block scale enables the identification of the cumulative effect of individual actions. A cluster, in turn, represents a set of unit blocks, delimited according to user criteria. In the current study, the clusters were delimited based on the identification of the HSA. Finally, the catchment is the study area, or the set of clusters (MITCHELL, 2005).

The input required for the model are climate data, water use, and spatial and calibration parameters. The surfaces identified in the spatial parameters are divided into pervious (gardens and open public spaces) and impervious (roofs, sidewalks, and streets). With the input data provided by the user and the model algorithms, Aquacycle generates daily, monthly, and annual water balance simulations at the three spatial scales. The model can be calibrated comparing simulated and measured flows.

\section{Climate Data}

Daily precipitation, potential evapotranspiration, and streamflow data between 2002 and 2013 were used. Precipitation and the other parameters necessary to determine the potential evapotranspiration were obtained from the climatological station located in the Belém catchment. After obtaining and processing the data, the potential evapotranspiration was calculated using the Penman-Monteith method (ALLEN et al., 1998), the most accepted method among the scientific community due to its range of parameters and complexity. For model calibration, the observed daily flow series measured in the stream gauge were used. 


\section{Water Use Data}

In the Aquacycle modelling framework, water use data should be uniform across the catchment, given in per capita consumption in L/day according to the number of residents in each household. Per capita water consumption varies from 102 to $291 \mathrm{~L} /$ inhab/day among the neighborhoods located in the study area (BREMBATTI, 2014), resulting in an average of 200 L/inhab/day. The consumption for residences with different numbers of inhabitants was calculated linearly. For example, consumption in a house with only one inhabitant will be 200 liters, while a house with two inhabitants will consume 400 liters, a house with three inhabitants will be 600 liters, and so on. The consumption was also distributed by type of use (kitchen, bathroom, toilet and laundry) due to the water reuse modeling options that Aquacycle presents. It is emphasized that the water reuse modeling tools were not used in this research.

\section{Spatial Parameters}

The spatial parameters input file is composed of a sequence of fourteen data points at the cluster scale, with information about land use, average occupancy per household, number of blocks (city lots) and water-supply system leakage. The procedures used to obtain each of these elements are described below.

Land use data were obtained through interpretation of a mosaic of seventeen high-resolution orbital images, provided by DigitalGlobe (satellite constellation composition, that result in about $60 \mathrm{~cm}$ resolution) made available by Google Earth Pro. Streets, open public spaces, and blocks with a spatial configuration different from the standard found in each HSA were fully vectorized with cartographic accuracy of $2 \mathrm{~m}$ and a scale of 1:10.000.

For the blocks with similar spatial configuration, some base blocks were selected in each HSA for integral mapping. The number of vectorized blocks in each HSA ranged from three to ten, depending on the total cluster area. The standard deviation calculated for mapped blocks in the same cluster showed that there is no significant statistic variation among their land use types. Subsequently, these base blocks provided the basis for calculating the proportionality of each category of inhomogeneous non-vectorized blocks. Due to spatial heterogeneity, HSA 1, 3 and 5 were completely vectorized.

Among other purposes, the average occupancy per household is a parameter used by Aquacycle to define the volume of water consumption in each HSA. As the study area includes a large number of non-residential establishments that consume significant volumes of drinking water, the average occupancy per household was proportionally altered to represent micro measure volumes per pressure zone (SANEPAR, 2010). That is, to fit the model data entry format, the use of water in nonresidential areas was calculated by artificially increasing the resident population.

The number of blocks per cluster, in turn, was defined based on the Municipality's registered division of city lots (IPPUC, 2013). Therefore, each lot of land was considered a unit block. For water supply system leakage, it was adopted a value of $40 \%$ (CURITIBA, 2013).

The Aquacycle model design does not consider wastewater inflow into stormwater drainage. Although this practice is illegal, it is a recurrent situation in Brazilian cities, including the Belém catchment (CURITIBA, 2013; BOLLMAN and EDWIGES, 2008). As sewage inflow into stormflow drainage represents a significant volume in the Belém catchment, it was necessary to include it in the water balance. The numerical solution found was to add it to the water-supply system leakage, whereas its volume is added to the baseflow and, consequently, to the streamflow.

There are disagreements among the official numbers regarding the volume of wastewater inflow into the Belém River, varying from the almost insignificant volume generated from 130 households to $40 \%$ of the total sewage generated in the catchment (SUDERSHA, 2002; IBGE, 2010; FENDRICH, 2002). Based on the best modelling performance in the calibration process, the volume adopted in this analysis was $46 \%$.

\section{Calibration and Validation}

The initial calibration parameters were performed according to the current literature and later adjusted based on comparisons between observed and simulated hydrograms. The methods used to compare the flows were: good replication of the quantity $(S I M / R E C)$ and coefficient of efficiency $(E)$ (MITCHELL, 2005).

\begin{tabular}{|c|c|}
\hline & Uberlândia-MG \\
\hline
\end{tabular}


SIM/REC is the sum of the simulated flow (SIM) divided by the sum of the measured flow $(R E C)$ on annual scale. SIM/REC = 1 means that the simulated and measured flow volume over time is equal, although not necessarily with the same temporal pattern. In turn, the coefficient of efficiency $(E)$ expresses the percentage of variance between the measured and simulated flow, according to equation 1:

$$
E=\left(\sum_{i=1}^{n}\left(R E C_{i}-\overline{R E C}\right)-\sum_{i=1}^{n}\left(R E C_{i}-S I M_{i}\right)^{2}\right) \div\left(\sum_{i=1}^{n}\left(R E C_{i-1}-\overline{R E C}\right)^{2}\right)
$$

where $\overline{\mathrm{REC}}$ is the average value recorded in the selected period, $\mathrm{REC}_{\mathrm{i}}$ is the measured value at the time $i$ and SIM $_{i}$ is the value simulated at the time i. Negative values indicate poor simulation. Values close to 1 indicate that the model can satisfactorily reproduce the measured streamflow.

In the current study, the reference period used for calibration and validation with the SIM/REC and $E$ parameters was the year 2010.

\section{HSA configuration and the water balance components analysis}

The results provided by Aquacycle modeling, for annual water balance are used to analyze the relations established between the urban space configuration and the water balance components volume response. The reference parameter in each HSA to define the urban space configuration is the percentage of impervious areas. It is noteworthy that studies such as Mitchell et al. (2001), Tucci (2002, 2008), Lekkas et al. (2008), Lee et al. (2010), and Mejía (2014), show that the percentage of impervious area is an indicator of the urbanization process, being able to synthesize several elements related to the hydrological processes in urban watersheds.

The components of the water balance analyzed in this research are streamflow, surface runoff, baseflow, infiltration, and groundwater recharge. In addition to the numerical and graphical analysis, linear regression was performed to assess how much the percentage of impervious areas in each HSA is able to explain the volume response of each component analyzed in the urban water balance.

\section{RESULTS AND DISCUSSION}

\section{Calibration and Validation Results}

The Aquacycle model was calibrated based on the simulation of daily hydrological dynamics between 2002 and 2013. The year used for calibration and validation procedures was 2010. Good replication of the quantity (SIM/REC) and coefficient of efficiency (E) reference period used for calibration presented values 0,93 and 0,57, respectively, that are considered acceptable by Mitchell (2005).

Because of the model's integrated approach, stormwater, wastewater, and water use calibration parameters must also be considered. For some parameters, the same reference values were used for all HSA (Table 1), to other parameters, however, it was necessary to adopt individualized values (Table 2) due to the particularities of each of them. 
Table 1 - Calibration parameters common to all Hydrologic Similarity Area.

\begin{tabular}{cccc}
\hline OUTPUT & CALIBRATION PARAMETER & UNITS & VALUE \\
\hline \multirow{4}{*}{ Stormwater } & Roof area maximum initial loss & $\mathrm{mm}$ & 2,3 \\
& Paved area maximus initial loss & $\mathrm{mm}$ & 2,4 \\
& Road area maximum initial loss & $\mathrm{mm}$ & 2,4 \\
& Effective road area & $\%$ & 100 \\
& Base flow index & ratio & 0,52 \\
& Base flow recession constant & ratio & 0,0291 \\
\hline Wastewater & \% of surface runoff as inflow & $\%$ & 15 \\
\hline \multirow{2}{*}{ Water Use } & Garden trigger to irrigate & ratio & 0 \\
& Public open space trigger to irrigate & ratio & 0 \\
\hline & Source: organized by the authors. & &
\end{tabular}

Table 2 Calibration parameters with stormwater output. Individualized values for each Hydrologic Similarity Area

\begin{tabular}{cccccccccccccccc}
\hline Calibration Parameters & Unit & $\mathbf{1}$ & $\mathbf{2}$ & $\mathbf{3}$ & $\mathbf{4}$ & $\mathbf{5}$ & $\mathbf{6}$ & $\mathbf{7}$ & $\mathbf{8}$ & $\mathbf{9}$ & $\mathbf{1 0}$ & $\mathbf{1 1}$ & $\mathbf{1 2}$ & $\mathbf{1 3}$ & $\mathbf{1 4}$ \\
\hline Percentage area store 1 & $\%$ & 70 & 90 & 90 & 90 & 70 & 90 & 90 & 40 & 90 & 90 & 90 & 90 & 90 & 90 \\
Pervious storage 1 capacity & $\mathrm{mm}$ & 24 & 11 & 11 & 11 & 24 & 11 & 11 & 27 & 11 & 11 & 11 & 11 & 11 & 11 \\
Pervious storage 2 capacity & $\mathrm{mm}$ & 86 & 86 & 86 & 86 & 86 & 86 & 86 & 220 & 86 & 86 & 86 & 86 & 86 & 86 \\
Effective roof area & $\%$ & 39 & 91 & 62 & 97 & 40 & 68 & 69 & 41 & 73 & 72 & 64 & 81 & 77 & 77 \\
Effective paved area & $\%$ & 39 & 91 & 62 & 97 & 40 & 68 & 69 & 41 & 73 & 72 & 64 & 81 & 77 & 77 \\
\hline
\end{tabular}

Source: organized by the authors.

The following assumptions were adopted to define the calibration parameters for the Belém catchment:

Stormwater: The soils of HSA 8 are originated from the Granitic-Gneiss Complex, which makes them more permeable than the others HSA. The soils of HSA 23467910111213 and 14 have low natural permeability, because they are originating from Guabirotuba Formation and Recent Sediments. Fendrich (2002) points out that these kinds of soil have a maximum infiltration capacity of about 86 $\mathrm{mm} /$ day. The soils of HSA 1 and 5 originate from the Guabirotuba Formation and Recent Sediments, but these areas are less urbanized. Consequently, the soil infiltration capacity is slightly higher than the others HSA in this same natural permeability condition. Roof maximum initial loss is equal to 2.3 $\mathrm{mm} /$ day. For streets and paved areas, the maximum initial loss is $2.4 \mathrm{~mm} /$ day. Arnell (1989, as quoted in FENDRICH, 2002) indicates that the initial loss in uncovered impervious areas varies between 2 and $6 \mathrm{~mm}$. All street areas are 100\% effective. The Sutherland equation (2000) for highly connected basins, expressed in equation 2, was adopted to determine roof and paved area maximum initial loss:

$$
E I A=0.4 \times(T I A) 1.2
$$

where EIA is the effective impervious area and TIA is the total impervious area.

Baseflow index $(0,52)$ and baseflow recession constant $(0,0291)$ were obtained from the observed streamflow series using the BFLOW program.

Wastewater: $15 \%$ of the surface runoff from the impervious areas flows into the sewer network.

Water use: irrigation practices were disregard in the modelling because of the study area's climatic characteristics. 


\section{Urban configuration and water balance}

The Aquacycle model was calibrated based on the simulation of daily hydrological dynamics between 2002 and 2013. The summary of results for annual water balance (in $\mathrm{mm}$ ) is presented in Figure 3 for the $14 \mathrm{HSA}$ delimited in the study area. The figure also presents the results from land use data for each HSA, showing that the percentage of impervious surfaces varies between $45 \%$ (HSA 1) and $97 \%$ (HSA 4), with an average of $72 \%$ in the catchment.

Figure 3 - Simulation results for the HSA and catchment scales for water balance parameters and the percentage of impervious surface area.

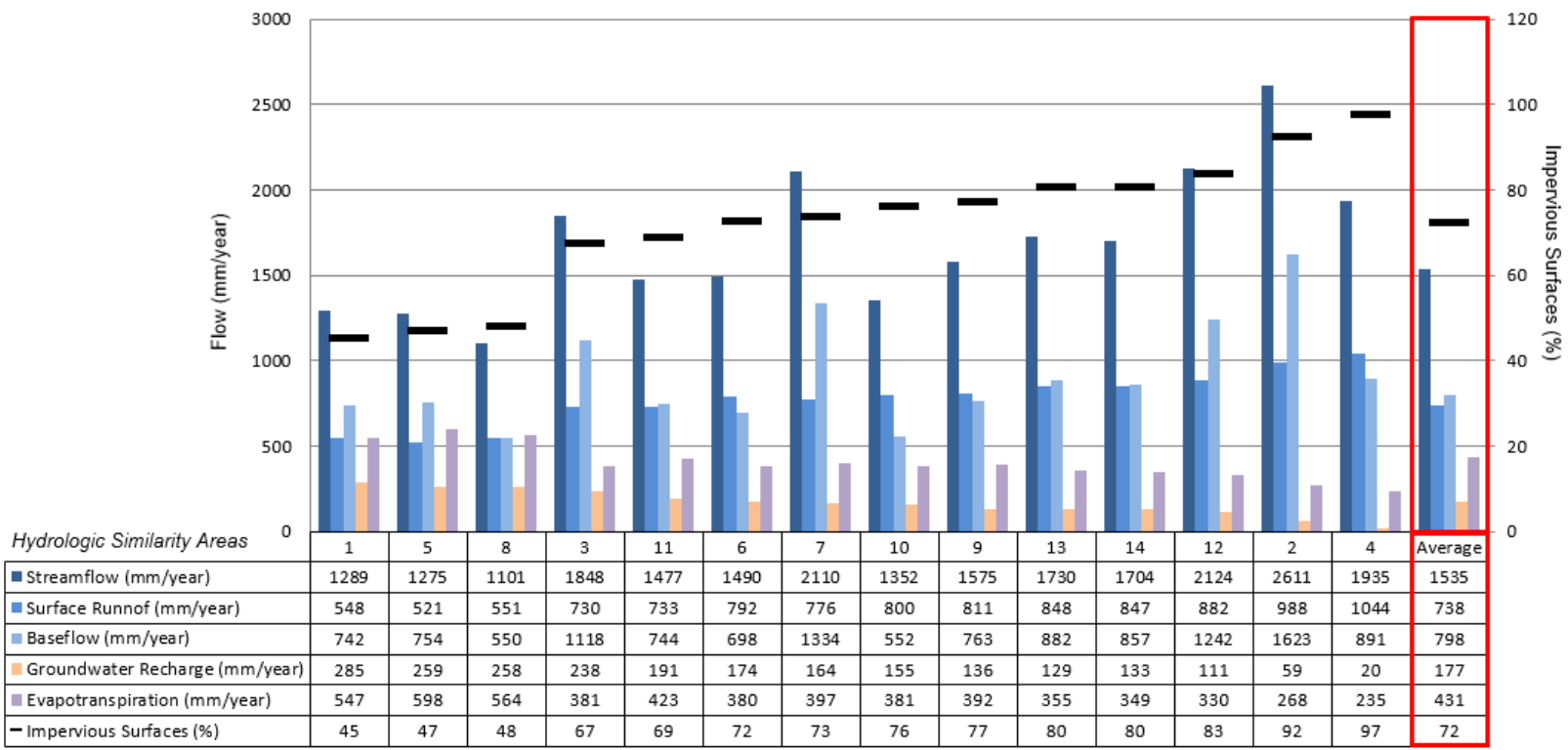

Source: organized by the authors.

As is generally expected in urban basins, the percentage of impervious surface area influenced the behavior of the water balance components. For example, the units with the highest percentage of impervious surfaces (HSA 4 and 2) have the highest volumes of surface runoff (1044 mm/year and $988 \mathrm{~mm} /$ year), while the units with the lowest percentages of impervious surface area (HSA 1, 5 and 8) present runoff volumes $(548,521$ and $551 \mathrm{~mm} / \mathrm{year}$, respectively) lower than the catchment average (738 mm/year).

An inverse relationship is observed when evapotranspiration or groundwater recharge and percentages of impervious surface area are compared. The units with the highest percentage of impervious surfaces represent scenarios with the lowest evapotranspiration ( 235 and $268 \mathrm{~mm} / \mathrm{year}$ ) and groundwater recharge (20 and $59 \mathrm{~mm} / \mathrm{year}$ ). The units with the lowest percentage of impervious surfaces present volumes of 547, 598 and $564 \mathrm{~mm} /$ year for evapotranspiration and 285, 259 and 258 $\mathrm{mm} /$ year for groundwater recharge.

Despite these identified correlations, the simulation results show that other local urban configuration characteristics also influence components of the water balance. Figure 4 shows the relationship between each of the simulated urban water balance components with the percentage of impervious surface area for the different HSA considered in the catchment, as well as the trend line and correspondence relation $\left(\mathrm{R}^{2}\right)$ obtained by linear regression. 
Figure 4 - Linear regression between the urban water balance components and percentage of impervious surface area.
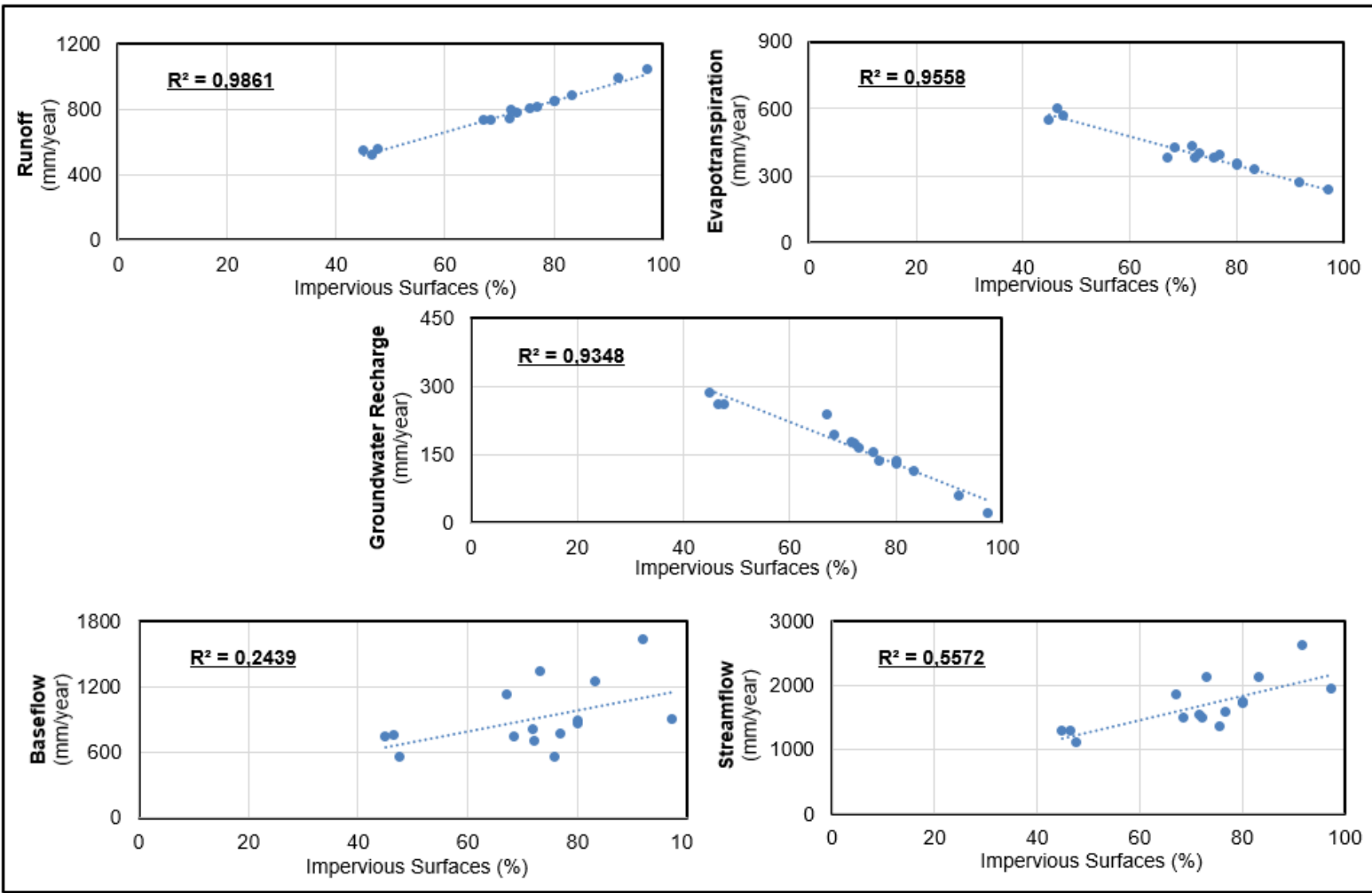

Source: organized by the authors.

As expected for urban basins, impervious surfaces have a strong influence on surface runoff, evapotranspiration, and groundwater recharge. However, the results suggest that baseflow and streamflow are less dependent on land use. According to Mejía et al. (2014), an inverse relationship between the percentage of impervious area and the baseflow is expected. For the Belém catchment, not only it is observed that the baseflow did not respond to the percentage of impervious surfaces as expected, but also that this behavior appears to be independent of the other components of the hydrological cycle. This indicates that baseflow behavior is independent of precipitation.

The fact that baseflow is independent of precipitation and consequently does not respond to land use changes demonstrates a common feature in Brazilian urban catchments, which receive large amounts of external water from water-supply system leakage and wastewater into stormwater drainage. In this case, the results indicate that baseflow behavior depends mainly on the HSA population density, and less on the physical characteristics of the catchment. Considering that the average rainfall (1450 $\mathrm{mm} / \mathrm{year}$ ) was lower than the average baseline $(1535 \mathrm{~mm} / \mathrm{year})$ for the observed period, the contribution of imported water in the catchment streamflow is evident.

In general, it appears that HSA with lower percentages of impervious surface areas (1,5 and 8) also have low population density. In these HSA, streamflows are lower than the catchment average and the contribution of baseflow is higher than runoff due to the significant contribution of water through groundwater recharge. HSA with streamflows higher than the catchment average present high percentages of impervious surfaces (2, 7 and 12), a small contribution of groundwater recharge, and a baseflow greater than runoff. These results can be explained by the high demographic density in these areas. The HSA with a high percentage of impervious surface area and lower population density $(4,6$, 9 and 12), however, present a runoff contribution higher than the baseflow contribution, again demonstrating the dependent relationship between baseflow and population density. 


\section{CONCLUSIONS AND RECOMMENDATIONS}

In the current study, the Aquacycle integrated hydrological model was used to simulate the urban water balance in the Belém catchment, Curitiba, Paraná. The study area was compartmentalized into $14 \mathrm{HSA}$, which have different spatial configurations in terms of percentages of impervious areas, zoning, and population density.

The results showed that the relationship between the urban configuration, with the increase in impervious areas, the increased surface runoff, and the decreased infiltration and evapotranspiration are direct and linear, as reported by Mejía et al. (2014). However, streamflow and baseflow parameters showed no sensitivity to the percentage of impervious surfaces.

These results can be explained due to the nature of water resource management issues in the Brazilian and Latin American contexts. The low sensitivity response of baseflow to t*he percentage of impervious surface area is due to the large volume of water-supply system leakage and wastewater inflow into stormwater drainage. Therefore, the limited response of baseflow to the percentage of impervious surfaces is reflected in the streamflow dynamics.

It is also determined that demographic density influences the baseflow due to water-supply system leakage and wastewater inflow into stormwater drainage. The annual average streamflow volume was higher than the annual average precipitation volume, also showing the influence of imported water on the baseflow composition.

With regards to spatial compartmentalization into HSA, it is confirmed the potential application of this conceptual model and its use in urban environments to identify fragilities and potentialities of each HSA which can inform planning, water resource management, and risk management purposes. It is recommended the use of the model in other study areas to verify its applicability in different catchments and further refine the methodology by including other variables that may influence the water dynamics in urban watersheds.

Finally, it is reiterated Nagendra's (2018) argument that studies focused on the particularities of urban development in Global South countries, with their specific demands and possibilities, must be promoted and further developed. The current research, therefore, adds to the strengthening of Brazilian and Latin American Urban Hydrology.

\section{ACKNOWLEDGEMENTS}

The authors would like to acknowledge CAPES for granting the PhD scholarship (40001016035P1) to Juliana Wilse Landolfi Teixeira de Carvalho, Postgraduate student in Geography at the Federal University of Paraná.

\section{REFERENCES}

ABNT - Associação Brasileira de Normas Técnicas. NBR 9649: Projeto de redes coletoras de esgoto sanitário. Rio de Janeiro, 1986. Available in: <https://docgo.net/detail-doc.html?utm_source=nbr-9649nb-567-projeto-de-redes-coletoras-de-esgoto-sanitario-pdf> Access in 10/01/2019.

ALLEN, R. G.; PEREIRA, L. S.; RAES, D.; SMITH, M. Crop evapotranspiration: Guidelines for computing crop water requirements. FAO Irrigation and Drainage Paper 56. Food and Agriculture Organization of the United Nations: Roma, 1998.

BOLLMANN, H. A.; EDWIGES, T. Avaliação da qualidade das águas do Rio Belém, Curitiba-PR, com emprego de indicadores quantitativos e perceptivos. Engenharia Sanitária e Ambiental, Rio de Janeiro, v. 13, n. 4, p. 443-452, out./dez., 2008. doi: 10.1590/S1413-41522008000400013 https://doi.org/10.1590/S1413-41522008000400013

BOTELHO, R. G. M. Bacias hidrográficas urbanas, edited by Guerra, A. J. T., 71-115. Rio de Janeiro: Bertrand Brasil, 2011

BREMBATTI, K. 2014 Alguns bairros de Curitiba gastam três vezes mais água que outros. Gazeta do Povo, Curitiba, December 4. Available in: <http://www.gazetadopovo.com.br/vida-e-cidadania/algunsbairros-de-curitiba-gastam-tres-vezes-mais-agua-que-outros-eh0054jg7f7ivu35nlp19yvym $>$ Access in 10/01/2019. 
CURITIBA MEMORY HOUSE. Último ato de um drama. Correio de Notícias, September 15, 1978a. 1978b. Canalização do Rio Belém: anseio curitibano de 80 anos. A Voz do Paraná, September 29,

CURITIBA. Plano Municipal de Saneamento de Curitiba: PMS. Prefeitura Municipal de Curitiba, 2013. Available in: <https://www.curitiba.pr.gov.br/conteudo/plano-municipal-de-saneamento-basico-decuritiba/1111> Access in 01/12/2018.

CURITIBA. Zoneamento e uso do solo: Legislação Municipal uso e ocupação do solo - leis e decretos complementares. Prefeitura Municipal de Curitiba, 2015 Available in: $<$ https://www.curitiba.pr.gov.br/conteudo/legislacao-zoneamento/220> Access in 28/11/2018.

DESTRO, C. A. M. 2016. The urban water use model as a tool to support the evaluation of sustainable drainage measures in brazilian cities. 2016. $156 \mathrm{f}$. Tese (Doutorado em Filosofia, Recursos Hídricos e Engenharia Ambiental) - Setor de Tecnologia, Universidade federal do Paraná, Curitiba, 2016. Available in: < https://acervodigital.ufpr.br/handle/1884/46507> Access in 30/01/2019.

FENDRICH, R. 2002. Diagnóstico dos recursos hídricos da bacia hidrográfica do rio Belém. Assembléia Legistaliva do Paraná (1).

IBGE - Instituto Brasileiro de Geografia e Estatística. Censo 1980. Available in: $<$ https://biblioteca.ibge.gov.br/index.php/biblioteca-catalogo?view=detalhes\&id=772> Access in 10/02/2019.

$\overline{01 / 02 / 2019 .}$

Censo 2010. Available in: <http://censo2010.ibge.gov.br/resultados/resumo> Access in

IPPUC - Instituto de Pesquisa e Planejamento Urbano de Curitiba. Shapes Curitiba. 2013. Available in: <http://ippuc.org.br/geodownloads/geo.htm> Access in 20/08/2018.

LARSEN, T. A.; HOFFMANN, S.; LÜTHI, C.; TRUFFER, B.; MAURER, M. Emerging solutions to the water challenges of an urbanizing world. Science, New York, v. 352, issue 6288, p. 928-933, may 2016. doi:

10.1126/science.aad8641.

https://doi.org/10.1126/science.aad8641

LAST, E.; MACKAY, R. Developing a new scoping model for urban water sustainability. In: $2^{\circ}$ Switch Scientific Meeting, 25-29 nov, 2007, Tel-Aviv, 2007.

LEE, J; PAK, G.; YOO, C.; KIM, S.; YOON, J. Effects of land use change and water reuse options on urban water cycle. Journal of Environmental Sciences, $n^{\circ}$ 22(6), p. 923-928, 2010. https://doi.org/10.1016/S1001-0742(09)60199-6

LEKKAS, D. F.; MANOLI, E.; ASSIMACOPOULOS, D. Integrated urban water modelling using the Aquacycle model. Global NEST Journal, v. 10, n. 3, p. 310-319, 2008. doi: 10.30955/gnj.000532 https://doi.org/10.30955/gni.000532

LEOPOLD, L. B. Hydrology for urban land planning: a guidebook on the hydrologic effects of urban land use. U.S. Geological Survey, Washington, 1968. https://doi.org/10.3133/cir554

MEJÍA, A.; DALY, E.; ROSSEL, F; JOVANOVIC, T.; GIRONAS, J. A stochastic model of streamflow for urbanized basins. Water Resources Research, 50, p.1984-2001. 2014. doi:10.1002/2013WR014834.

https://doi.org/10.1002/2013WR014834

MINEROPAR - Minerais do Paraná S.A. Atlas Geomorfológico do Estado do Paraná: Escala base 1:250.000, modelos reduzidos 1: 500.000. Minerais do Paraná; Universidade Federal do Paraná. Curitiba, 2006.

Available

in: $<$ http://www.mineropar.pr.gov.br/arquivos/File/2_Geral/Geomorfologia/Atlas_Geomorforlogico_Parana _2006.pdf> Access in 30/01/2019.

MITCHELL, V. G., MEIN, R.; MCMAHON, T.A. Modelling the urban water cycle. Journal of Environmental Modelling and Software, $\mathrm{n}^{\circ}$ 16, p. 615-629, 2001. doi: 10.1016/S1364-8152(01)000299. https://doi.org/10.1016/S1364-8152(01)00029-9

MITCHELL, V. G. Aquacycle User Guide. CRC for Catchment Hydrology. Monash University, Melbourne, Australia, 2005.

MITCHELL, V. G. DIAPER, C. UVQ: a tool for assessing the water and contaminant balance impacts of urban development scenarios. Water Science \& Technology, vol. 52, n. 12, p. 91-98, 2005. https://doi.org/10.2166/wst.2005.0435 
NAGENDRA, H.; BAI, X.; BRONDIZIO, E. S.; LWASA, S. The urban south and the predicament of global sustainability. Nature Sustainability: London, v. 1, p 341-349, jul. 2018. https://doi.org/10.1038/s41893-018-0101-5

SANEPAR - Companhia de Saneamento do Paraná. Cadastro técnico 2010. SANEPAR's database.

SCHNEIDER, A., FRIEDL, M. A. AND POTERE, D. A new map of global urban extent from MODIS satellite data. Environmental Research Letters, v. 4, 2009. https://doi.org/10.1088/1748-9326/4/4/044003

SHARMA, A. K.; GRAY, S.; DIAPER, D.; LISTON, P.; HOWE, C. Assessing integrated water management options for urban developments - Canberra case study. Urban Water Journal, London, Elsevier B.V., vol. 5, n. 2, p. 147-159, jun 2008. https://doi.org/10.1080/15730620701736829

SUDERSHA - Superintendência de Desenvolvimento de Recursos Hídricos e Saneamento Ambiental. Tomo 4.8 Modelagem das linhas de inundação da bacia do rio Belém. In: Plano diretor de drenagem para a bacia do rio Iguaçu na região metropolitana de Curitiba. Curitiba, 2002. Available in: $<$ http://www.aguasparana.pr.gov.br/pagina-265.html> Access in 20/02/2019.

SUTHERLAND, R. C. Methods for estimating the effective impervious area of urban watersheds. The Practice of Watershed Protection, Article 32, 193-195, 2000.

TUCCI, C. E. M. Gerenciamento da drenagem urbana. RBRH- Revista Brasileira de Recursos Hídricos. Porto Alegre. v.7, n.1, p. 5-27, jan-mar, 2002. https://doi.org/10.21168/rbrh.v7n1.p5-27

Águas Urbanas. Estudos Avançados. v. 22, n. 63, p. 97 a 112, 2008. https://doi.org/10.1590/S0103-40142008000200007

. Regulamentação da drenagem urbana no Brasil. REGA- Revista de Gestão de Água da América Latina, Porto Alegre, v. 13, n. 1,p. 29-42, jan./jun. 2016. https://doi.org/10.21168/rega.v13n1.p29-42

UN-HABITAT. World Cities Report 2016: Urbanization and development, emerging futures. United Nations Human Settlements Programme, Kenya: 2016. Available in: <https://www.unhabitat.org/wpcontent/uploads/2014/03/WCR-\%20Full-Report-2016.pdf> Access in 03/03/2019.

VERSINI, P. A.; KOTELNIKOVA, N.; POULHES, A.; TCHIGUIRINSKAIA, I.; SCHERTZER, D.; LEURENT, F. A distributed modelling approach to assess the use of Blue and Green Infrastructures to fulfil stormwater management requirements. Landscape and Urban Planning, Elsevier B.V. v. 173, p. 60-63, fev. 2018. https://doi.org/10.1016/..landurbplan.2018.02.001

Recebido em: 16/04/2020

Aceito para publicação em: 01/10/2020 